Article

\title{
Food Citizenship and Governmentality: Neo-Communitarian Food Governance in The Hague
}

\author{
Shivant Jhagroe \\ Leiden University, Institute of Public Administration, 2511 DP The Hague, The Netherlands; \\ E-Mail: s.s.jhagroe@fgga.leidenuniv.nl
}

Submitted: 13 March 2019 | Accepted: 30 July 2019 | Published: 28 October 2019

\begin{abstract}
This article presents an account of food citizenship based on a governmentality framework. Moving beyond the dichotomy of democratic or neoliberal accounts of food citizenship, a food governmentality framework is presented. This Foucaultian inspired framework conceptualises food citizenship as identity formation in relation to various modes of power that govern food systems and subjects in significantly different ways. The article empirically illustrates how food citizenship relates to food governmentality by focussing on the food-related activities of a Transition Town initiative in the Netherlands (The Hague) called Den Haag In Transitie (DHIT). By defining food as a community issue, and employing holistic-spiritual and collaborative knowledge, food citizens in the DHIT case render sustainable food systems governable in radically new ways. I argue that this type of citizenship can be considered neo-communitarian food citizenship and moves beyond democratic or neoliberal accounts. Finally, the article reflects on neo-communitarian citizenship and argues for a nuanced understanding of food citizenship, moving away from either democratic romanticism or neoliberal criticism.
\end{abstract}

\section{Keywords}

food citizenship; food democracy; governmentality; neoliberalism; Transition Towns

Issue

This article is part of the issue "New Perspectives on Food Democracy" edited by Basil Bornemann (University of Basel, Switzerland) and Sabine Weiland (Université Catholique de Lille, France).

(C) 2019 by the author; licensee Cogitatio (Lisbon, Portugal). This article is licensed under a Creative Commons Attribution 4.0 International License (CC BY).

\section{Introduction}

Today, an increasing number of citizens are challenging agro-industrial food systems. These 'food citizens' address a wide range of problems, such as the commercial focus of food companies, the poor quality of processed food, environmental harm and unfair food infrastructures (Spaargaren, Oosterveer, \& Loeber, 2013). Food citizens typically seek to pursue a more "democratic, socially and economically just, and environmentally sustainable food system" (Wilkins, 2005, p. 271). Growing research on both food citizenship and food democracy has shown how citizens actively participate in challenging dominant food systems and shaping alternative ways to produce, distribute and consume food (cf. Booth \& Coveney, 2015). Over the years, different aspects of food citizenship have been studied, including political consumerism, community gardening, and anti-capitalist food activism. In gen- eral terms, food citizenship can be considered a sociopolitical praxis that indicates an effort to make food systems more democratic and sustainable (Bonanno \& Wolf, 2017; de Tavernier, 2012). According to Gómez-Benito and Lozano (2014), food citizenship is even considered a precondition for a more sustainable society: "Just as democracy cannot exist without democratic citizens, a sustainable society cannot exist without ecological citizens and sustainable alimentation cannot exist without food citizens" (p. 139). However, critical scholars also raise questions about new forms of power and discipline associated with food citizenship. They reproach the emancipatory potential of food citizens and argue that food citizens are actually enrolled in a broader neoliberal regime of power that foregrounds individual responsibility and ethical food markets within the boundaries of a capitalist society (Drake, 2014; Laforge, Anderson, \& McLachlan, 2017; Lockie, 2009; McClintock, 2014). This 
critique paints a fundamentally different picture of what food citizenship actually entails in relation to the creation of sustainable food systems.

This article discusses these opposing accounts of food citizenship and presents a different conception of food citizenship, based on a governmentality framework. It does so by critically assessing two food citizenship frames: (1) an emancipatory democratic one; and (2) a self-management oriented neoliberal one. These frames have significantly different assumptions about citizenship, power and agency. A major weakness in both accounts is how they selectively highlight opposing aspects of food citizenship. Moving beyond a democratic/neoliberal dualism of food citizenship, a 'food governmentality' framework is presented in the following section. A Foucaultian inspired approach enables a broader understanding of specific types of citizenship in relation to strategies that seek to govern food systems (Dean, 2010; Fletcher, 2010). Adapting Fletcher's work of environmental governmentality, this section proposes food governmentality as a conceptual approach that allows for a nuanced understanding of how food citizenship is enacted and related to different food governing regimes. Importantly, a governmentality approach to food citizenship defines agential power neither as democratic nor as repressive, but as complex identity formation related to different modes of power that render subjects and food systems governable in various ways (Laforge et al., 2017). The article then presents the empirical case of a grassroot initiative in The Hague called Den Haag In Transitie (The Hague In Transition [DHIT]), and centre-stages their efforts to create sustainable food networks. As such, the DHIT case empirically illustrates food citizenship from a governmentality perspective. Empirical data is derived from qualitative data sources (documents, interviews, field notes) and reflected upon with the analytical dimensions of the proposed food governmentality approach. By defining food as a community issue, and employing holisticspiritual and collaborative knowledge, food citizens in the DHIT case render sustainable food systems governable in radically new ways. I argue that this type of citizenship can be considered neo-communitarian food citizenship and moves beyond democratic or neoliberal accounts. Finally, the article reflects on neo-communitarian citizenship and argues for a nuanced understanding of food citizenship, moving away from either democratic romanticism or neoliberal criticism.

\section{Framing Food Citizenship}

This section presents two contrasting accounts of food citizenship, a democratic and a neoliberal one. Even though food citizenship research is vast and heterogenous, I use these accounts and this distinction to discuss two prevalent ways to understand food citizenship and their limitations. First, a dominant focus in food citizenship research is on how civic engagements and active cit- izenship transform the agro-industry and food retail. This scholarly work underlines the democratic quality of food citizenship, challenging passive food consumerism and centre-staging citizenship as a political force to take control of food systems (e.g., Wilkins, 2005). However, some scholars criticise democratic food citizenship and argue that emancipation through food citizenship actually resonates with a neoliberal discourse of individual moral responsibility and local Do-It-Yourself practices (Schindel Dimick, 2015). They question the very idea of 'democratic emancipation' underlying food citizenship by pointing to their perpetuation of neoliberal regimes of power. In the next section, these two accounts are briefly discussed, with a particular emphasis on how each conceives agency and power.

\subsection{Democratic Food Citizenship}

Food citizenship can be seen as an emancipatory notion that highlights why and how citizens see food as a democratic issue (Booth \& Coveney, 2015; Bonanno \& Wolf, 2017). As Renting, Schermer, and Rossi (2012) note, since the notion of food citizenship emerged in North American scholarship it has basically focussed on civic ways to organise food systems. Welsh and MacRae (1998) even indicate that the concept was used to highlight "the need to move beyond food as a commodity and people as consumers" (p. 237). This democratic narrative challenges agro-industrial forces and resonates with the concept of food democracy that also gained currency in the 1990s. Food citizenship is deeply intertwined with food democracy. The latter offers a perspective that underscores how passive and uninformed food consumers turn into active citizens who take (back) control over 'their' food systems (Lang \& Heasman, 2015). In recent years, the discursive label of 'food citizenship' even inspired an actual social movement committed to raise awareness and self-organise. As the Foodcitizenship website notes: "Food Citizenship is a growing movement of people acting as interdependent participants in a food system, not just as producers or consumers in linear supply chains" (Food Citizenship, n.d.). This collaborative New Citizenship Project seeks to "catalyse the shift from Consumer to Citizen as the dominant idea of the individual in society: The Citizen Shift" (Food Citizenship Report, 2014, p. 2). Despite some differences in form and scope, it seems that most food citizens enact democratic agency by pursuing radical change of the global agro-industrial complex. Food movements also draw attention to food injustices (e.g., 'food deserts,' excessive 'food miles,' and 'nutritional inequality'). Food, then, serves as an entry point to address larger structures of social and economic inequality. All in all, food is considered a medium for democratic emancipation, as Hassanein argues (2003, p. 83): “Food democracy ideally means that all member of an agrofood system have equal and effective opportunities for participation in shaping that system as well as knowledge about the relevant alternative ways of de- 
signing and operating the system." Importantly, transforming local food systems has been at the forefront of many food movements. It includes developing ample local food-related knowledge and skills, while pressuring policy makers into offering systemic alternative food infrastructures (Wilkins, 2005).

This democratic account seems to dominate in food citizenship research. Citizenship is conceptualised as political agency that challenges normalised capitalist subjectivity. As Gómez-Benito and Lozano (2014) argue: "Food citizens involves the pre-condition of the subject's (the citizen's) autonomy and ability to define and exercise her food preferences" (p. 150). Even though democratic food citizenship differs from a classical Marxist approach to take over the 'means of food production,' it foregrounds developing radically alternative means to organise food networks. A democratic frame highlights how food citizens employ both radical and pragmatic practices to democratise food systems: protests, demonstrations and boycotts, and community gardening. As such, democratic food citizenship seeks to govern global and local food systems 'from below' by foregrounding a wide variety of civic actions.

\subsection{Neoliberal Food Citizenship}

The emancipatory democratic commitment of food citizens, however, has been challenged. Food citizenship has been especially subjected to neoliberal critique. Critics highlight the dominance of market forces and an ideology of self-managing individualism. Even though emancipation of consumers and food citizens is considered an asset, they 'tragically' enter a sticky cobweb of power relations. In particular, a neoliberal frame highlights the commodification and individualisation of responsibility of food citizenship. This significantly reduces the ways in which food citizenship is defined and comes into being. Importantly, in the domain of commercial markets and individual choice-making, sovereign power might be absent, but structures of power persist in much more subtle forms (Guthman \& Brown, 2016). For instance, uneven socio-economic relations of power can accommodate elitist food citizenship practices, for instance, as lowincome groups cannot afford high priced organic foods (Hamilton, 2005). Neoliberal critics note that democratic food citizenship has a blind spot for power relations and unwanted side effects.

A neoliberal understanding of food citizenship, as supported by some scholars, criticises the 'autonomy' of food citizens and its democratic claim in two ways. First, food citizens are considered as political consumers that pursue the purchase of 'eco-labelled' food, and enact their citizenship in a field dominated by market forces. Pursuing a 'radical' green lifestyle within the boundaries of a market system takes pragmatic adjustments as realistic and desirable. The emblematic figure of the 'citizenconsumer' bears witness to an economic subject pursuing ethical food choices in the marketplace (Lockie, 2009).
Second, and related, even though food citizens typically reject central power in the food system, it may fit a neoliberal agenda with a minimal state and austerity measures (Harris, 2009; McClintock, 2014; Prost, Crivellaro, Haddon, \& Comber, 2018). This somewhat ironic emancipation underscores how bottom-up food systems resonate with a neoliberal culture of personal and local responsibility (organic farmers' markets and community gardens). Importantly, the apparent 'democratisation' of food citizenship, is considered a form of privatisation of responsibility at best. Schindel Dimick (2015) notes that neoliberal citizenship is conceived "as a private moral obligation rather than as an activity that occurs with others in a political community" (p. 395). So, neoliberal food citizens relate to food governance in roughly two ways: (1) The 'fetish' for market mechanisms (Guthman, 2007); and (2) the privatisation of responsibility. Neoliberal governance feeds on a fine-grained and decentred web of both economic and social power. It is of particular interest in the domain of sustainable food because it moves away from command-and-control rule and classical market logics (Rose, 1999). As many critics of neoliberal governance have argued, this pervasive modality of self-disciplining power undermines the deeply public and political character of food (Goodman, DuPuis, \& Goodman, 2012).

\section{Beyond the Dichotomy: A Food Governmentality Framework}

It seems that both accounts of food citizenship have diverging conceptions of power and agency, and consequently, what it means to be a food citizen. State power plays a different role as different state-citizenship relations are assumed. In a democratic account, the state provides ample regulatory space for all kinds of citizen activities to emerge and develop alternative food practices. The neoliberal account, however, assumes that the state actively accommodates market mechanisms and policy measures that promote individual responsibility. Importantly, whereas democratic food citizenship argues that taking control over food systems is ultimately emancipatory, neoliberal food citizenship notes that this is actually an insidious way for food regimes to extend and refine power. It assumes an underlying conceptual dichotomy between democratic agential power on the one hand and the perpetuation of neoliberal food governance on the other hand.

This dichotomy is problematic. These diverging and dualist conceptions of agency reduce conceptual and empirical understandings of layered and ambivalent forms of power. Alternative food networks are complex and composite, and can be expected to maintain, challenge but also transcend democratic and neoliberal forms of agency (Alkon \& Guthman, 2017; Ghose \& Pettygrove, 2014). It thus requires a conceptualisation of food citizenship that is directly related to food governance beyond the vocabulary of democratic or neoliberal practices. 
This broader scope is important because it allows us to understand how specific food citizen practices relate to related regimes of power and governance. It provides more context to the emergence and practice of food citizenship 'on the ground.' As some scholars have argued, generic labels such as 'neoliberalism' can create blind spots that downplay different forms and variations of political governance (Bevir, 2016; Hindess, 2002). Heuristics such as 'food democracy' or 'neoliberal governance' are useful to make sense of specific changes in how citizens and power relate. However, the emergence of new social actors in traditional food systems, the proliferation of alternative food networks, and changes in how food systems are defined, can all give rise to new food governing arrangements. It would be reductionist to downplay these shifts and heterogeneities regarding food governance strategies. Food citizenship research runs the risk of translating new and situated instances of food citizenship as either emancipatory or neoliberal moralisation.

\subsection{Governmentality}

When moving away from a democratic/neoliberal dichotomy, it is instructive to draw on Foucaultian governmentality scholarship, mainly because it rejects any opposition between emancipation and domination. Michel Foucault introduces the notion of governmentality in his 1978 and 1979 Collège de France lectures. Governmentality is based on the deconstruction of opposing hierarchical oppressive (state) power and voluntary human conduct. It focusses on how power uses both coercion and emancipation to shape specific social identities. In general terms, governmentality refers to "rationalities and technologies that seek to guide human beings" (Lemke, 2013, p. 38). This may include a wide range of governing practices and forms of power (such as formal sovereignty, moral discipline). Power, then, is actually not repressive but productive. Power creates specific realities and allows identity positions to come into being and unfold. This is crucial, as it enables a conceptualisation of citizenship that emphasises how regimes of power are instrumental in shaping the identity of citizens. Often, governmentality includes specific rationalities that are messy and even contradictory (Lemke, 2013). As Nadesan puts it: "Governmentality recognizes that social fieldsthe state, the market, and population-are in fact heterogeneous spaces constituted in relation to multiple systems of power, networks of control, and strategies of resistance" (Nadesan, 2008, p. 10). Significantly, a governmentality perspective moves away from institutional and liberal approaches to power that ask: Who gets what, when and how? Instead, it focusses on how power is actually exercised through specific practices and regimes (Methmann, 2011). As Bröckling, Krasmann, and Lemke (2011, p. 11) state: "[T]he main focus here is on the technologies and rationalities of (self-) government in distinct fields. The knowledge incorporated in governmental practices is always practical knowledge." Even though governmentality researchers often have different definitions of governmentality, they agree on the fact that a governmentality approach is flexible and investigates:

Mechanisms of conduct of 'people, individuals or groups' (Foucault, 2007: 102, 120-122), extending from management of company employees to the raising of children and daily control practices in public spaces to governing trans-national institutions such as the European Union and the United Nations. (Bröckling et al., 2011, p. 11)

If we zoom in on the domain of food, it suggests that food citizen practices should be understood in how they actually come into being in broader networks of power and governing. The 'heterogeneity of power and resistance' is important, as it allows us to move outside frames that reduce power to either emancipatory or neoliberal power. Food citizens are both 'subjects' and 'objects' of power. Food citizenship, then, is a more complex identity that might, but does not merely fit a democratic or neoliberal mould. Ironically, as Bevir (2016) argues, governmentality research often reduces new modes of governance to neoliberal governance (regarding food issues see e.g., Guthman \& Brown, 2016). Occasionally, another form of food governance is discussed, such as food governance through nutritional spirituality and nutritional politics (Coveney, 1999; Swislocki, 2011). But, how should what I call food governmentality be understood without linking it directly to democratic or neoliberal modes of power? And how should food governmentality relate to food citizenship?

\subsection{Food Governmentality}

I argue that food governmentality refers to a heterogenous set of specific practices that renders food systems visible, knowable and governable in particular ways. The relationship between specific forms of seeing, forms of knowing, and forms governing on the one hand, and specific social identities on the other hand, is crucial from a governmentality perspective. For instance, the use of statistical knowledge by state agencies in the 18th century gave rise to the category of 'the population' as an object that could be studied, visualised and governed. From a governmentality perspective, this means that 'food citizenship' emerges through particular regimes and practices. The conceptualisation of governmentality according to Dean (2010) is instructive here, as it is specific and flexible enough to translate into a food governmentality approach. Governmentality for Dean focusses on the "organized practices through which we are governed and through which we govern ourselves, what we shall call here regimes of practices or regimes of government" (Dean, 2010, p. 28). For the sake of analytical clarity and consistency, it is fruitful to characterise food governmentality on the basis of four analytical dimensions as discussed by Dean (2010, see also Haahr, 2004): 1) visibil- 
ity of food; 2) knowledge about food; 3) food governing techniques; and 4) food-related subject formation.

(1) Visibility of food: Food is never just food. Food and food systems are seen, sensitised and defined in particular ways. Food can, for instance, be considered as a legal, an economic or a social issue. As regards this dimension of visibility, we may ask by what kind of light (drawings, flow charts, maps, graphs, tables, etc.) a field illuminates and defines 'food objects' and with what shadows and darkness it obscures and hides others.

(2) Knowledge about food: Relatedly, food and food systems emerge as particular objects of knowledge. Food systems can be understood and known in particular ways, depending on specific forms of expertise and know-how about food systems. The dimension of the knowledge is concerned with the forms of thought, knowledge, expertise, strategies, means of calculation or rationality that are employed in the practices of governing food systems.

(3) Food governing techniques: Certain material practices and instruments are employed to design and steer food systems into a particular direction. The dimension of the governing technique asks the question by what means, mechanisms, procedures, tactics, techniques, technologies and vocabularies authority is constituted and the rule of food systems is accomplished.

(4) Food-related subject formation: A fourth dimension concerns the forms of individual and collective identity through which governing operates. What forms of person, self and identity related to food are presupposed by different practices of food governing and what sorts of transformation do these practices seek?

Food citizenship, as a particular type of identity formation, directly resonates with the fourth of these dimensions. However, and as argued earlier, food citizen practices are deeply entangled with the other dimensions that make up a broader food governing regime. In this approach, food identities (such as food citizens) cannot be isolated from broader food governing practices. The strength of this approach is exactly its emphasis on how food subjects come into being by being inscribed in broader regimes of knowledge and power.

\subsection{Types of Food Governmentality}

Unsurprisingly, there is not one type of food governmentality. An interesting contribution that allows for a differentiated framing of food governmentality comes from Fletcher (2010). Fletcher's work focusses on environmental governmentality and different modes of governing the 'environment' (Agrawal, 2005; Fletcher, 2017). Building on Fletcher's typology of environmentality and translating it into the specific domain of food governance, we can articulate four 'food governmentalities' (Fletcher, 2010, p. 177):

(1) Indigenous food governmentality: Holistic connections with food, based on evolutionary and indigenous knowledge;
(2) Disciplinary food governmentality: Creating food subjects, based on diffusing ethical norms;

(3) Sovereign food governmentality: Governing food systems based on legal practices and regulations;

(4) Neoliberal food governmentality: Commodifying food, based on market mechanisms and individualisation.

Fletcher's account of these governmentalities can be characterised along the lines of Dean's (2010) four analytical dimensions (see Table 1 ). This would provide a systematic typology of different food governmentalities, with their own particular ways of defining, knowing and governing food systems, and-ultimately-creating specific food identities.

The strength of this matrix is that it sensitises both the systematicity and heterogeneity of food governmentality as an analytical approach. That is to say, it allows for an analytical understanding of how food governing logics work in relation to food identities, while specifying a number of prevalent and actual governing logics. These governmentalities are in no way exhaustive or include all modes of governing 'out there.' The added value of a governmentality approach is exactly its focus on change and variety in how food systems are rendered sensible and governable. Furthermore, there is no neat overlap between these modes of food governmentality and citizenship on the one hand, and the two dominating accounts discussed earlier on the other hand (i.e., democratic and neoliberal citizenship). If that were the case, it would not allow for a significantly different conceptualisation of food citizenship. A food governmentality approach redefines food citizenship and puts it in its proper governing context. Yet, it should be mentioned that neoliberal food citizenship resonates to some extent at least with both neoliberal and disciplinary food governmentality (Guthman, 2007; Schindel Dimick, 2015). Food, then, is rendered governable through moral individual responsibility and market-driven mechanisms. In our day and age, neoliberal food governmentality seems to be a dominant way through which food systems are governed and food identities take shape (Bonanno \& Wolf, 2017). At the same time, new types of food systems and their governance emerge (e.g., farmers markets and community gardens). It is exactly through a variegated repertoire that different kinds of food citizenship and governance emerge and develop. As such, food citizens have the potential to reconfigure food systems and render them governable in unexpected ways.

\subsection{Food Governmentality and Democratic Citizenship?}

I do not subscribe to democratic food citizenship as simply an emancipatory force in the ways in which food systems are organised. However, it is instructive to briefly reflect on how food governmentality relates to democratic food citizenship and food democracy more broadly. How are they related? In what way do they conflict or 
Table 1. Food governmentalities.

\begin{tabular}{|c|c|c|c|c|}
\hline & $\begin{array}{l}\text { Indigenous food } \\
\text { governmentality } \\
\text { 'spirit and soil' }\end{array}$ & $\begin{array}{l}\text { Disciplinary food } \\
\text { governmentality } \\
\text { 'morals and guilt' }\end{array}$ & $\begin{array}{l}\text { Sovereign food } \\
\text { governmentality } \\
\text { 'fences and fines' }\end{array}$ & $\begin{array}{l}\text { Neoliberal food } \\
\text { governmentality } \\
\text { 'markets and lifestyles' }\end{array}$ \\
\hline $\begin{array}{l}\text { 1. Visibility of } \\
\text { food }\end{array}$ & $\begin{array}{l}\text { Food as a spiritual } \\
\text { object }\end{array}$ & $\begin{array}{l}\text { Food as a moral } \\
\text { object }\end{array}$ & $\begin{array}{l}\text { Food as a legal } \\
\text { object }\end{array}$ & $\begin{array}{l}\text { Food as a commercial } \\
\text { object }\end{array}$ \\
\hline $\begin{array}{l}\text { 2. Knowledge of } \\
\text { food }\end{array}$ & $\begin{array}{l}\text { Holistic and 'indigenous' } \\
\text { knowledge of food }\end{array}$ & $\begin{array}{l}\text { Morality, ethics, } \\
\text { health/medical } \\
\text { science }\end{array}$ & $\begin{array}{l}\text { Food regulations, } \\
\text { rules, strategic } \\
\text { planning }\end{array}$ & $\begin{array}{l}\text { Food markets, } \\
\text { consumer preferences, } \\
\text { economics }\end{array}$ \\
\hline $\begin{array}{l}\text { 3. Food governing } \\
\text { techniques }\end{array}$ & $\begin{array}{l}\text { 'Do it ourselves', } \\
\text { community } \\
\text { engagement }\end{array}$ & $\begin{array}{l}\text { Shame and guilt, } \\
\text { scientific reasoning }\end{array}$ & $\begin{array}{l}\text { Fines, rights and } \\
\text { obligations }\end{array}$ & $\begin{array}{l}\text { Privatisation, food labels, } \\
\text { competition, individual } \\
\text { responsibility }\end{array}$ \\
\hline $\begin{array}{l}\text { 4. Formation of } \\
\text { food subjects }\end{array}$ & $\begin{array}{l}\text { Spiritual subjects and } \\
\text { food communities }\end{array}$ & $\begin{array}{l}\text { Ethical and moral } \\
\text { food citizens }\end{array}$ & $\begin{array}{l}\text { Law-abiding food } \\
\text { suppliers and citizens }\end{array}$ & $\begin{array}{l}\text { Food consumers, } \\
\text { industrial food suppliers }\end{array}$ \\
\hline
\end{tabular}

Source: Adapted from Fletcher (2010).

intersect? Instead of considering a romantic image of localism or indigenous food communities ('spirit and soil') as intrinsically tied to democratic citizenship, democratic emancipation does not have a clear place in a governmentality approach. However, as Foucault famously argues "where there is power, there is resistance, and yet, or rather consequently, this resistance is never in a position of exteriority in relation to power" (Foucault, 1990, p. 95). So actually, resisting and redirecting power allows for innovation, creativity and shifts in how dominant (food) regimes and (food) citizen practices are governed (Miller \& Rose, 1990). It, then, could be argued that this is precisely what the promise of food democracy and the democratic account of food citizenship entails, as it seeks to reshape the organisation and operations of food systems. It challenges the global agro-industrial powers that be, while seeking new ways to organise food production and distribution (Booth \& Coveney, 2015). Importantly, an account of 'democratic citizenship as resistance' moves away from classical liberal or republican conceptions of agency and citizenship that dominate citizenship-related research (Bickford, 1996; Gabrielson, 2008). A more radical understanding of democratic emancipation and food democracy, then, foregrounds how practices of resistance redefine food systems and their governance. Introducing new ways to visualise, know and organise food systems by social actors is how a dominant food governmentality can take shape (Dean, 2010, p. 44). A democratic food citizen in a governmentality approach, then, is not a specific and stable identity that can be attained. Rather, it illuminates the contingency, experimentation and variety of food identities in direct relation to how food systems are governed.

\section{The Case of DHIT: Food Citizenship and Governance in The Hague}

This section presents food citizen practices of a Dutch Transition Town initiative in the city of The Hague (DHIT).
DHIT is presented as a critical case that serves to empirically show how food citizenship is related to food governmentality (Flyvbjerg, 2006). Empirical materials are based on policy documents and semi-structured interviews with DHIT member and policy makers (see Appendix). DHIT members I interviewed are mostly young people (age 20-40) with a cosmopolitan worldview and commitment to local sustainability. Some have an activist background and/or experience with social movements in the 'Global South.' Virtually all members are committed to healthy and sustainable food. The policy makers I interviewed are related to The Hague's sustainability programme, either strategic policy actors or street-level policy actors that frequently contact citizens groups and local companies. In addition, ethnographic field research has been conducted for 4-6 months in the DHIT network in late 2013 to early 2014. As a participant, I joined dozens of meetings and initiatives organised by DHIT, which provided much information about how DHIT relates to food (as an organisation and as individual members). The empirical materials have been categorised and coded, primarily on the basis of the four analytical dimensions of the proposed food governmentality framework ('selective' or 'theoretical' coding; cf. Saldaña, 2015). Before zooming in on the DHIT case, it is instructive to briefly contextualise it.

For decades, food security has been a key concern in EU countries. Food regulations have set high security and safety standards for agro-industrial food systems. Multinationals and market actors have developed food systems at the expense of food quality and the environment (Spaargaren et al., 2013). Against this background, and climate change more broadly, the global Transition Town movement emerged in the early 2000s. Typically, a Transition Town initiative seeks to develop self-reliant communities that produce socio-environmental goods, such as healthy and sustainable food, and renewable energy. In the Dutch city of The Hague, a Transition Town network called DHIT was established after a movie night 
about the Transition Town movement in November 2012. This movie, watched by around 40 people, led to debates about global and local issues related to climate change and the economic crisis. The local production and selforganisation of food plays a pivotal role in the DHIT network, even though DHIT also engages in sustainable mobility, energy and other issues. For the sake of this contribution, food-relates issues are foregrounded in this section. Even though DHIT members do not explicitly describe themselves as 'food citizens', most of their activities express some form of food citizenship.

\subsection{DHIT and Visibility of Food}

For DHIT, food primarily emerges as a socio-political issue with the potential to shape new communities. Many DHIT members consider industrial food in the Netherlands as unnatural and artificial, analogous to the artificial identity of a passive consumer. During my fieldwork, a DHIT participant said that he was not satisfied with tomatoes from the supermarket, because they "taste different from the ones you grow yourself." Similarly, he argued, home-grown cucumbers have a particular taste: "they are almost sweet, very different, a lot of people don't know this...we lose the original taste and nutritional value of food" (Interview A). DHIT members often argue that our understanding of what kind of materials and fertilisers are used in food are unknown to the wider public. Some DHIT members more generally criticise the food system for its mystification of extracting materials and nutrition in distant places (Interview B). They explicitly politicise the wider economic system and the ways in which sustainability concerns are linked to issues of global inequality and poverty (Interview A; Interview B; Interview C). As one active DHIT member put it:

[Our society and economic system] is presented as normal, in schools and in our parenting. We are taught that this is the only choice we have...but things are distributed unevenly, everything is unequal. Almost everything we enjoy in the Netherlands has a negative impact on the rest of the world. For example, the amount of land we need for our food consumption actually exceeds the physical space of the Netherlands itself." (Interview B)

DHIT members share knowledge about food and related socio-environmental concerns in many ways. They organise movie nights and have discussions about a range of topics, including the suffering of animals, carbon emissions and litter. Typically, scientific information about the food problem (e.g., statistics about food waste) is interwoven with analysing root causes of the problem and possible solutions. Apart from the initiatives of specific food-related awareness or workshops events, connecting food initiatives is a key focus for DHIT. In some instances, these connections are literally visualised with the help of other actors. For example, edible plants and fruits in public space are visualised via a digital map (Edible The Hague). Policy makers and urban residents can also geographically locate specific sustainability initiatives (e.g., a community garden or an energy cooperative) on an interactive digital map designed by city authorities (Haagse Krach-kaart). These maps seem to accommodate ways of seeing sustainable food infrastructures outside the prevailing agro-industrial regime (major food producers and supermarkets). By doing this, DHIT shapes new ways of sensing and foregrounding 'real' or 'forgotten' food, as part of a communityoriented and just food system.

\subsection{DHIT and Knowledge of Food}

Specific types of knowledge shape this local food community. Non-Western knowledge, spirituality and holistic framings of food are used and play an important role for DHIT members. Some engage in holistic thinking or spiritual philosophies that centre-stage links between physical and mental health, food and the wellbeing of animals. A wide range of ideas combine spiritualism and activist work, such as deep ecology exercises, radical interdependencies (e.g., regarding global food systems and meat consumption), ethical permaculture principles (which is translated in the main DHIT vision) and yoga exercises (creating physical and mental fitness and resilience). For these DHIT members, a human being is a spiritual being intricately linked to social and ecological systems. The body and mind should therefore be respected by eating nutritional, proper and pure food, but also mentally by doing yoga or thinking holistically (Interview D and Interview G). Interestingly, this does not mean that such ways of holistic thinking are not used by traditional policy actors. In fact, many policy actors observed and thought about urban areas and districts in terms of vital and dynamic sites with 'different energies.' Such spaces, from the viewpoint of the municipality, require very little legal regulation but a tailored approach and policy practices informed by "acupuncture" (Interview I). Policy actors in The Hague consider the city in terms of a fluid and 'thermodynamic system.' That is to say, in addition to (or instead of) having formal legal citizenship, some active residents or neighbours are considered potential ambassadors for their street or neighbourhood. This new sense of seeing and knowing flexible food networks is expressed by frequently sharing information and knowledge about new initiatives or events. This knowledge is also produced and exchanged by workshops, events and Do-It-Yourself maps and brochures to let residents take up initiatives themselves (e.g., urban farming, or making one's home energy efficient).

\subsection{DHIT and Food Governing Techniques}

As a grassroot organisation, DHIT does not rely on formal regulations or classical market-driven techniques to 
render the local food systems governable. They actually try to move beyond governmental and commercial approaches to governing food systems. The DHIT network employs a wide range of social practices to establish, support, cultivate and glue together local sustainable food initiatives. Such community shaping practices are enacted via guerrilla gardening, sharing food, volunteering and cooperation with policy makers. These practices move beyond an individualist culture with consumerbased practices of buying processed food, owning stuff for yourself, and living in a 'concrete jungle' on your own. They seem to be accompanied by means to re-connect one's 'outer' and 'inner' world. These self-disciplining techniques include doing yoga, meditation and being vegan. Even though not all DHIT participants employ these methods, they play a specific role, namely to 'purify' oneself and to engage in new types of relations with other human beings, animals and ecologies. Furthermore, DHIT has been thinking and talking about upscaling local food production and urban farming in The Hague for some time (Interview A, Interview D, Interview $\mathrm{E}$ and Interview F). Urban farming and growing your own food are advocated and practiced by some, for example, growing tomatoes, cucumber and all kinds of herbs. This kind of food activism challenges large-scale and profit-based food systems that are considered to offer 'cheap, unfair, unnatural and unhealthy' products. DHIT tries to engage in outreach regarding food in different ways. They offer workshops about urban farming to all kinds of organisations, in which they for instance teach others how to grow food even if space is limited to a balcony (using 'balcony farming'; Interview A).

\subsection{DHIT and Formation of Food Subjects}

DHIT shapes a sustainable food community and social identities in different ways. While some could be considered as actively involved in health or food, other participants were more into organising events, planning meetings and external cooperation. DHIT members are part of a broader active citizenry aimed at making food systems sustainable and just. DHIT members cooperate with a range of local organisations that are also committed to healthy and sustainable food (e.g., Healthy Soil, Food Coop The Hague, Edible Den Haag, Sustainable Studios). They cooperate with other initiatives on the basis of specific food-related events or projects. Given its broad orientation (food and non-food issues), DHIT has particular target groups in mind, which enables a focussed strategy to work together with organisations and to raise awareness about health and sustainable food in The Hague. Cooperation could even develop into a broader regional sustainable food system. DHIT has published a document about how a regional food system could be based on an interrelated network of producers, distributors and farmers markets (Bredius, 2013). Even though market mechanisms are considered relevant here (supply and demand), they are considered ethical as they are locally embedded and create local and community value. The discourse of urban farming has also entered the local political and administrative system. In 2011, four local political parties proposed a so-called 'urban food strategy' for the city of The Hague (Party for the Animals, Labour Party, The Hague City Party, Green Party, 2011). In this document, a number of progressive political parties argue that food and urban farming have many advantages for city life including public health and the regional economy. This document was taken seriously by the local government and translated into an official food strategy in 2013 (Municipality of The Hague, 2013). Interestingly, coordination between DHIT and policy actors is prevalent, as DHIT would accommodate the sustainable development of The Hague "from below," whereas the municipality would do the same "from above," as they put it (Interview H). In recent years, policy actors have become much more invested in city life outside the formal policy domain. In the context of sustainability and food, they attend workshops and barbeques, and sometimes have informal evening calls with small entrepreneurs (Interview H). Such flexible policy actors are actively involved in this food community while navigating between formal procedures and citizen projects with 'good energy'.

\section{Towards Neo-Communitarian Food Citizenship}

One could read the DHIT case as an instance of democratic citizenship or even see traces of neoliberal citizenship. However, as discussed above, I seek to understand the DHIT case neither as an expression of emancipatory democratic food citizenship, nor as an example of neoliberal citizenship. The democratic or neoliberal frames would only highlight the case in particular ways, and leave out significant aspects. It can be said that the DHIT case resonates with 'indigenous' and 'disciplinary' forms of food governmentality (see Section 3 and Table 1). At the same time, however, DHIT seems to move away from classical state power (sovereign) and profit-oriented market mechanisms and individualism (neoliberal). What is key is the intersection of a holistic approach and diffusion of food ethics and the role of a food community 'in the making.' This is not surprising, as local communities play a significant role in shaping food democracies (Laforge et al., 2017). I argue that the DHIT case centre-stages a community-oriented way of seeing and governing food outside agro-industrial systems. However, this community is not a static network with a fixed number of people and type of community members. Rather, it is better to consider it as a 'community assemblage,' meaning a loosely coupled set of actors, activities and networks entangled with DHIT. They might do different things, with slightly different histories and aims. An assemblage is a useful notion here, inspired by the work of Deleuze and Guattari, as it emphasises "immanent modes of association...that are capable of inventing alternative forms of social interaction" (Krause \& Rölli, as cited in ScottCato \& Hillier, 2010, p. 871). These pragmatic alterations 
accommodate complex community-driven power that governs sustainable food systems, while being open to democratic change.

What particular type of food governmentality does the DHIT case express then? I argue that this governing rationale can be called neo-communitarian food governmentality. 'Neo' in this neologism signifies a novel and more fluid mode of community relations, compared to communitarianism with its socially shared and geographically bounded traditions (cf. Bell, 2015). Neocommunitarian food governance resonates slightly with a neoliberal frame, as it highlights self-organisation and a sense of actively taking up one's 'own responsibility' in the food system (cf. Schinkel \& van Houdt, 2010). However, to argue that the DHIT case fits in the same neoliberal basket as political consumerism does harm to the complexity and range of DHIT activities. Neo-communitarian governmentality conflicts with neo-liberal governmentality, in that, it employs other forms of knowledge, state practices and social norms. State power, for instance, plays a specific role in democratic and neoliberal accounts of food citizenship (see Section 3). Neo-communitarian citizenship assumes a flexible role for policy makers that actively participate in food communities. Furthermore, citizens are not considered as individually responsible for sustainable food practices (typically via the marketplace), but as social beings part of a broader community. More technically, one could say that a neo-communitarian food citizen (different from a neoliberal one) is a political subject shaped by a heterogenous and community-oriented form of knowledge and practices. So, to what extent do food-related activities of DHIT express democratic food citizenship? It highlights the double-edge sword of grassroot food activism as a democratic force and a new regime of selfdisciplining power. Even though community-driven efforts to design and organise new food systems can be considered as inherently democratic (Hassanein, 2003), the rise of a food community comes with new and subtle forms of disciplinary authority, linked to spirituality, social norms and pragmatic collaborations. As such, neocommunitarian food citizenship draws attention to the complexity of food citizenship beyond democratic emancipation or neoliberal power.

What does this mean for the key notion of food citizenship? First of all, most DHIT members can be considered as a 'food community making' network. Such food citizens emerge by engaging in producing environmental goods, outside the confines of formal policy making, but by a set of socio-environmental, economic, cultural and even spiritual practices. Importantly, for years, it has been (and still is) a strategic goal of city officials in The Hague to cultivate active citizens who start initiatives with the same goals as specific policy plans (e.g., urban farming or reducing food miles). Related to these food citizens, new institutional identities are shaped. It is clear that policy actors have become increasingly invested in city life 'outside' the city hall. They attend barbeques, have evening calls with citizens and meet with innovative entrepreneurs. Such policy actors navigate between formal procedures and citizen projects with 'good vibes and energy.' So, institutional actors are part and parcel of a sustainable food community that move between practices 'from below' and 'from above'. It challenges the notion of food citizens as clearly separated actors from formal governance actors.

\section{Concluding Remarks}

This contribution presented an account of food citizenship based on a governmentality framework. By providing a more critical understanding of food citizenship, it sketched a different image of food citizenship, and how it relates to food democracy. A number of conclusions can be drawn. First, the food governmentality framework proves to be quite fruitful in characterising how food citizenship relates to food governance, beyond democratic and neoliberal conceptions of food citizenship. It allows for a broader perspective on how food citizenship relates to different regimes of power. Food citizenship, from a governmentality framework, highlights the inherent fusion of power associated with food citizens: gaining power over food systems and being subjected to power. It is through specific ways of seeing, defining and knowing food (unhealthy/healthy, industrial/real, etc.) and governing food systems (Do-It-Yourself practices, local food networks), that a specific type of food citizen comes into being. Second, the DHIT case illuminates that food citizenship indeed relates to food democracy, as local food networks seek to take control of food production and distribution. However, it also creates new forms of self-disciplining power in the form a new food community. I call this flexible mode of self-governing power neo-communitarian governmentality. So, one could argue that a new form of disciplinary and directive power emerges when critique and experimentation turns into new community norms and knowledge about what entails 'sustainable food,' which partners are 'useful,' and which type of market mechanisms are 'ethical.' In other words, neo-communitarian citizens that shape this governing regime are also shaped by this regime. The consequent power ambivalences should be taken as a modus operandi. Food activism and food democracy can create very specific regimes of knowledge, social norms and social identities. Therefore, we should carefully understand the intricate power dynamics of food citizenship and expressions of food democracy worldwide. Third, neo-communitarian food citizenship should not be considered as a political identity that replaces democratic or neoliberal citizenship in any way. Rather, my account of food citizenship complements these frames and draws attention to the complex political dynamic underlying food citizenship. A more critical understanding of food citizenship and food governance could disclose new theoretical and empirical insights. Research on food democracy and food citizenship could, for instance, explore new food 
governmentalities by comparing cases from the 'Global North' and the 'Global South.' Food governmentality, as a complex arrangement of power, could also be conceptualised in relation to issues of food sovereignty and food justice (Desmarais, Claeys, \& Trauger, 2017). New research could further illuminate the analytical power and scope of food governmentality, and offer new perspectives on how food systems and power are related.

\section{Acknowledgments}

The author would like to thank the anonymous referees for their useful suggestions. Furthermore, the author would like to thank all respondents and DHIT members for their time and openness.

\section{Conflict of Interests}

The author declares no conflict of interests.

\section{References}

Agrawal, A. (2005). Environmentality: Technologies of government and the making of subjects. Durham, NC: Duke University Press.

Alkon, A., \& Guthman, J. (Eds.). (2017). The new food activism: Opposition, cooperation, and collective action. Berkeley, CA: University of California Press.

Bell, D. A. (2015). Communitarianism. Wiley Encyclopedia of Management, 2015, 1-3. https://doi.org/10. 1002/9781118785317.weom020091

Bevir, M. (Ed.). (2016). Governmentality after neoliberalism. London: Routledge.

Bickford, S. (1996). The dissonance of democracy: Listening, conflict, and citizenship. New York, NY: Cornell University Press.

Bonanno, A., \& Wolf, S. A. (Eds.). (2017). Resistance to the neoliberal agri-food regime: A critical analysis. London: Routledge.

Booth, S., \& Coveney, J. (2015). Food democracy: From consumer to food citizen. Singapore: Springer.

Bredius, L. (2013). Stadslandbouw: Collaborative urban farming. Een strategie in ontwikkeling [Urban agriculture: Collaborative urban farming. An unfolding strategy]. The Hague: DHIT.

Bröckling, U., Krasmann, S., \& Lemke, T. (Eds.). (2011). Governmentality: Current issues and future challenge. New York, NY: Routledge.

Coveney, J. (1999). The science and spirituality of nutrition. Critical Public Health, 9(1), 23-37.

de Tavernier, J. (2012). Food citizenship: Is there a duty for responsible consumption? Journal of Agricultural and Environmental Ethics, 25(6), 895-907.

Dean, M. (2010). Governmentality: Power and rule in modern society. Thousand Oaks, CA: Sage.

Desmarais, A. A., Claeys, P., \& Trauger, A. (Eds.). (2017). Public policies for food sovereignty: Social movements and the state. London: Routledge.
Drake, L. (2014). Governmentality in urban food production? Following "community" from intentions to outcomes. Urban Geography, 35(2), 177-196.

Fletcher, R. (2010). Neoliberal environmentality: Towards a poststructuralist political ecology of the conservation debate. Conservation and Society, 8(3), 171.

Fletcher, R. (2017). Environmentality unbound: Multiple governmentalities in environmental politics. Geoforum, 85, 311-315.

Flyvbjerg, B. (2006). Five misunderstandings about casestudy research. Qualitative Inquiry, 12(2), 219-245.

Food Citizenship. (n.d.). Homepage. Food Citizenship. Retrieved from https://foodcitizenship.info

Food Citizenship Report. (2014). Food citizenship: How thinking of ourselves differently can change the future of our food system (New Citizenship Project Report). London: New Citizenship Project. Retrieved from https://drive.google.com/file/d/OB0swicN11 uhbSGM2OWdCeXdQZGc/view

Foucault, M. (1990). The history of sexuality: An introduction, Vol. I. (R. Hurley, Trans.). New York, NY: Vintage.

Gabrielson, T. (2008). Green citizenship: A review and critique. Citizenship Studies, 12(4), 429-446.

Ghose, R., \& Pettygrove, M. (2014). Urban community gardens as spaces of citizenship. Antipode, 46(4), 1092-1112.

Gómez-Benito, C., \& Lozano, C. (2014). Constructing food citizenship: Theoretical premises and social practices. Italian Sociological Review, 4(2). http://doi.org/10. 13136/isr.v4i2.79

Goodman, D., DuPuis, E. M., \& Goodman, M. K. (2012). Alternative food networks: Knowledge, practice, and politics. London: Routledge.

Guthman, J. (2007). The Polanyian way? Voluntary food labels as neoliberal governance. Antipode, 39(3), 456-478.

Guthman, J., \& Brown, S. (2016). I will never eat another strawberry again: The biopolitics of consumercitizenship in the fight against methyliodide in California. Agriculture and Human Values, 33(3), 575-585.

Haahr, J. H. (2004). Open co-ordination as advanced liberal government. Journal of European Public Policy, 11(2), 209-230.

Hamilton, N. D. (2005). Food democracy II: Revolution or restoration. Journal of Food Law \& Policy, 1, 13.

Harris, E. (2009). Neoliberal subjectivities or a politics of the possible? Reading for difference in alternative food networks. Area, 41(1), 55-63.

Hassanein, N. (2003). Practicing food democracy: A pragmatic politics of transformation. Journal of Rural Studies, 19(1), 77-86.

Hindess, B. (2002). Neo-liberal citizenship. Citizenship Studies, 6(2), 127-143.

Laforge, J. M., Anderson, C. R., \& McLachlan, S. M. (2017). Governments, grassroots, and the struggle for local food systems: Containing, coopting, contesting and collaborating. Agriculture and Human Values, 34(3), 663-681. 
Lang, T., \& Heasman, M. (2015). Food wars: The global battle for mouths, minds and markets. New York, NY: Routledge.

Lemke, T. (2013). Foucault, politics and failure. In J. Nilsson \& S. O. Wallenstein (Eds.), Foucault, biopolitics, and governmentality (p. 35-52). Huddinge: Södertörn University.

Lockie, S. (2009). Responsibility and agency within alternative food networks: Assembling the "citizen consumer." Agriculture and Human Values, 26(3), 193-201.

McClintock, N. (2014). Radical, reformist, and gardenvariety neoliberal: Coming to terms with urban agriculture's contradictions. Local Environment, 19(2), 147-171.

Methmann, C. P. (2011). The sky is the limit: Global warming as global governmentality. European Journal of International Relations, 19(1), 69-91. https:// doi.org/10.1177/1354066111415300

Miller, P., \& Rose, N. (1990). Governing economic life. Economy and Society, 19(1), 1-31.

Municipality of The Hague. (2013). Voedselstrategie [Food strategy]. The Hague: Municipality of The Hague.

Nadesan, M. (2008). Governmentality, biopower and everyday life. New York, NY: Routledge.

Party for the Animals, Labour Party, HSP, \& GroenLinks. (2011). (H)eerlijk Haags. Een Initiatiefvoorstel Voor een Stedelijke Voedselstrategie [Fair and delicious The Hague. A proposal for an Urban Food Strategy]. The Hague: Party for the Animals, Labour Party, The Hague City Party, and Green Party.

Prost, S., Crivellaro, C., Haddon, A., \& Comber, R. (2018). Food democracy in the making: Designing with local food networks. In Proceedings of the $2018 \mathrm{CHI}$ conference on human factors in computing systems (pp. 1-14). New York, NY: ACM.
Renting, H., Schermer, M., \& Rossi, A. (2012). Building food democracy: Exploring civic food networks and newly emerging forms of food citizenship. International Journal of Sociology of Agriculture and food, 19(3), 289-307.

Rose, N. (1999). Powers of freedom: Reframing political thought. Cambridge: Cambridge University Press.

Saldaña, J. (2015). The coding manual for qualitative researchers. London: Sage.

Schindel Dimick, A. (2015). Supporting youth to develop environmental citizenship within/against a neoliberal context. Environmental Education Research, 21(3), 390-402.

Schinkel, W., \& van Houdt, F. (2010). The double helix of cultural assimilationism and neo-liberalism: Citizenship in contemporary governmentality. The British Journal of Sociology, 61(4), 696-715.

Scott-Cato, M., \& Hillier, J. (2010). How could we study climate-related social innovation? Applying Deleuzean philosophy to Transition Towns. Environmental Politics, 19(6), 869-887.

Spaargaren, G., Oosterveer, P., \& Loeber, A. (Eds.). (2013). Food practices in transition: Changing food consumption, retail and production in the age of reflexive modernity. London: Routledge.

Swislocki, M. (2011). Nutritional governmentality: Food and the politics of health in late Imperial and Republican China. Radical History Review, 2011(110), 9-35.

Welsh, J., \& MacRae, R. (1998). Food citizenship and community food security: Lessons from Toronto, Canada. Canadian Journal of Development Studies/Revue Canadienne d'études du Développement, 19(4), 237-255.

Wilkins, J. L. (2005). Eating right here: Moving from consumer to food citizen. Agriculture and Human Values, 22(3), 269-273.

\section{About the Author}

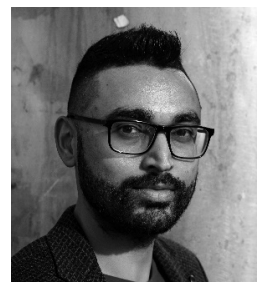

Shivant Jhagroe (PhD) is an Assistant Professor at the Institute of Public Administration, Leiden University. Jhagroe received his PhD degree from the Erasmus University Rotterdam in 2016. His doctoral thesis is titled Urban Transition Politics: How Struggles for Sustainability are (Re)Shaping Urban Spaces. His research interests cover to domains: environmental politics and justice; and algorithmic power and politics. Jhagroe draws on different disciplines, including Governmentality research, Political Ecology, and Science and Technology Studies. 
COGITATIO

\section{Appendix}

Table A1. List of interviews.

\begin{tabular}{|c|c|c|c|c|}
\hline & Reference & Affiliation & Interview date & Interview location \\
\hline 1 & Interview A & DHIT member & 11 January 2014 & The Hague, the Netherlands \\
\hline 2 & Interview B & DHIT member & 29 January 2014 & The Hague, the Netherlands \\
\hline 3 & Interview C & DHIT member & $\begin{array}{l}\text { Personal communication during fieldwork } \\
\text { (late } 2013 \text { to early 2014) }\end{array}$ & The Hague, the Netherlands \\
\hline 4 & Interview D & DHIT member & $\begin{array}{l}\text { Personal communication during fieldwork } \\
\text { (late } 2013 \text { to early 2014) }\end{array}$ & The Hague, the Netherlands \\
\hline 5 & Interview E & DHIT member & $\begin{array}{l}\text { Personal communication during fieldwork } \\
\text { (late } 2013 \text { to early 2014) }\end{array}$ & The Hague, the Netherlands \\
\hline 6 & Interview F & DHIT member & $\begin{array}{l}\text { Personal communication during fieldwork } \\
\text { (late } 2013 \text { to early 2014) }\end{array}$ & The Hague, the Netherlands \\
\hline 7 & Interview G & DHIT member & $\begin{array}{l}\text { Personal communication during fieldwork } \\
\text { (late } 2013 \text { to early 2014) }\end{array}$ & The Hague, the Netherlands \\
\hline 8 & Interview $\mathrm{H}$ & $\begin{array}{l}\text { Freelancer, related to } \\
\text { municipality of the Hague }\end{array}$ & 8 January 2014 & The Hague, the Netherlands \\
\hline 9 & Interview I & $\begin{array}{l}\text { Policy actor, Municipality } \\
\text { of the Hague }\end{array}$ & 14 January 2014 & The Hague, the Netherlands \\
\hline
\end{tabular}

